\title{
The effects of knowledge management capabilities on Research outcome and Teaching effectiveness in King Saud University
}

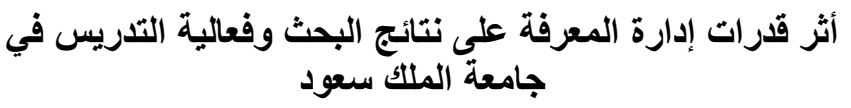

\begin{abstract}
The aim was to investigate effects of $\mathrm{KMC}$ on research outcome(RO) and teaching effectiveness(TE) in KSU. The final sample consisted of 320 University staff, from Humanities Colleges. Four faculties were selectively chosen. They were Colleges of Languages and Translation, Education, Sports Science and Physical Activity and Arts. PCA was conducted to measure the relationship between the study variables. SEM was employed to determine a valid causal model. Means, standard deviations, correlation, skewness and kurtosis among variables indicated that variables were highly correlated. The results revealed that KA has significant direct effects on both RO \& TE, KS has significant direct effects on both RO \& TE, KU has significant direct effects on both RO \& TE,TI has significant direct effects on both RO \& TE, and OC has significant direct effects on both RO \& TE.
\end{abstract}

Keywords: knowledge management capabilities, Research outcome, Teaching effectiveness, King Saud University.

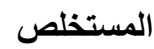

هدفت الدراسة الى الكثف عن ناثير قدرات إدارة المعرفة على نتائج البحث وفعالية التدريس في جامعة الملك سعود.

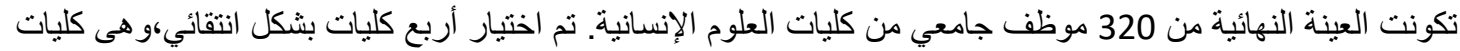

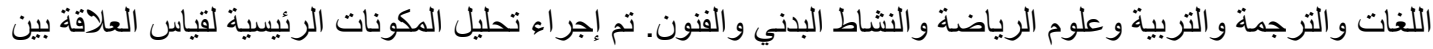

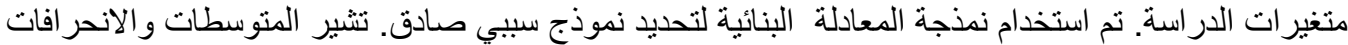

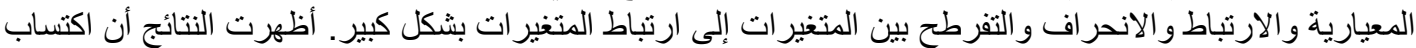

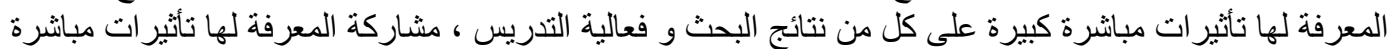

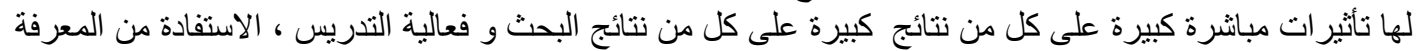

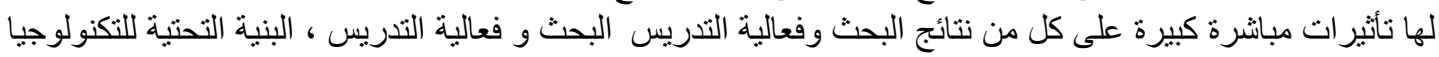

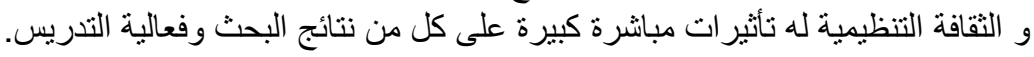

الكلمات المفتاحية: قدرات إدارة المعرفة ، نتائج البحث ، فعالية التدريس ، جامعة الملك سعود

\section{Introduction}

We live in a rapidly changing world. That is due to what is called new KE (Ali, Teong \& Othman, 2012). Accordingly, universities as HEIs are meeting the challenges. Universities are regarded to generate and disseminate knowledge (Omerzel, Biloslavo, \& Trnavčevič, 2011; Martínez, 2019). In order for any university to be competitive, it should adopt $\mathrm{KM}$, which is considered to be the core resource of an organization in such an economy (Wen-Ling \& Chun-Yen, 2016). KM includes four key steps (Maricris, Gerby \& Kimry, 2019).

${ }^{37}$ Associate professor, Educational Administration College of Education, King Saud University. 
Education lies at the heart of knowledge economies. Talents could not be produced if it were not for a qualified education as through HEIs, knowledge is imparted and distributed. It is clear that KM is of great value tool in meeting the institutions goals (Loh et al., 2010). These institutions should reveal and emphasize their ability to manage knowledge. In case they did, then they can utilize their management, administration, teaching and research resources, all of will improve research outcome and teaching effectiveness of these institutions (Wen-Ling \& Chun-Yen, 2016). KM services enriching knowledge sharing and performance as a whole (Hossain et al., 2013). It can play vital and dynamic role in HEIs through effective planning, organising, monitoring and coordinating the $\mathrm{KM}$ assets related to IC (Balakrishnan \& Chandramalar, 2019), as HEIs are driven by knowledge.

There are many paths through HEIs create new knowledge. These are: research, teaching and learning, research and development and communication (Balakrishnan \& Chandramalar, 2019). KM is supposed to be great benefits in higher-education environment in research process, curriculum development process, student and alumni services, administrative services and business strategic planning (Ammar, Lim \& Siti, 2012).

$\mathrm{KM}$ has gained acceptance in the academic domain in the last few years, since it becomes clear that universities play a major role in the knowledge economy, and this itself has brought new challenges for HEIs (Pinto, 2014). KM encourages university staff to collect and analyze information, transform knowledge and apply novelties (Machado, \& Davim, 2013).

HEIs should adopt KM for some reasons. First it is well known that, HEIs by their nature are supposed to be driven by knowledge, as such they are regarded as being in the knowledge business (Balakrishnan \& Chandramalar, 2019), since these institutions are empowered to produce, distribute and apply knowledge (Fullwood, Rowley \& Delbridge, 2013). This knowledge is supposed to be the final product of HEIs (Huang \& Lai, 2014). Second, there are great number of universities in our country, public and private, which on its side drives great competition. Third, ministry of higher education in our country cares much about the quality of courses HEIs offer to their students.

It is of great importance to understand the relationship between KM research outcome and teaching effectiveness in order for HEIs to be successful (Wen-Ling \& Chun-Yen, 2016). Some researchers (e.g. Muhammad et al., 2011) found that KG, KC, KS and KU have positive and significant relationships with research outcome and teaching effectiveness.

Although evidence indicates that KM can be of great importance in supporting HEIs in teaching and research activities; there is also evidence indicates that HEIs adopt approaches that can be described as passive and inconsistent (Donate \& Canales, 2012). So, as Cranfield \& Taylor (2008) suggested HEIs should understand well KM before they can begin to see the benefits on a wide level (Balakrishnan \& Chandramalar, 2019).

Saudi Arabia seeks to have a knowledge-based economy. Hence, it implements series of 5-years development plans, among them is ninth development plan (Abdulrahman, mohamad, najma \& imtiaz, 2018; Ministry of Economy and Planning, 2014). Some studies (e.g. Ammar, Lim, \& Siti, 2012; Cranfield, \& Taylor, 2008; Osama, Ramzi, Tillal, 2018) reveal the nature of KM in HEI and the urgent need to adopt information technologies that address the needs of the initiatives and practices However, little empirical research has been conducted to investigate the effects of knowledge management capabilities on research outcome and teaching effectiveness in King Saud university.

\section{Study questions}

1. Did the KMPC have effects on research outcome?

2. Did the KMPC have effects on teaching effectiveness?

3. Did the KMPC have mediating effects between research outcome and teaching effectiveness?

This study could contribute to the literature on KMC, research outcome and teaching effectiveness in $\mathrm{KSU}$, as HEIs do an important role in the knowledge-based economy.

\section{Methodology}

Study framework and methodology 
Data were gathered through questionnaires and manipulated SEM. See Figure 1.

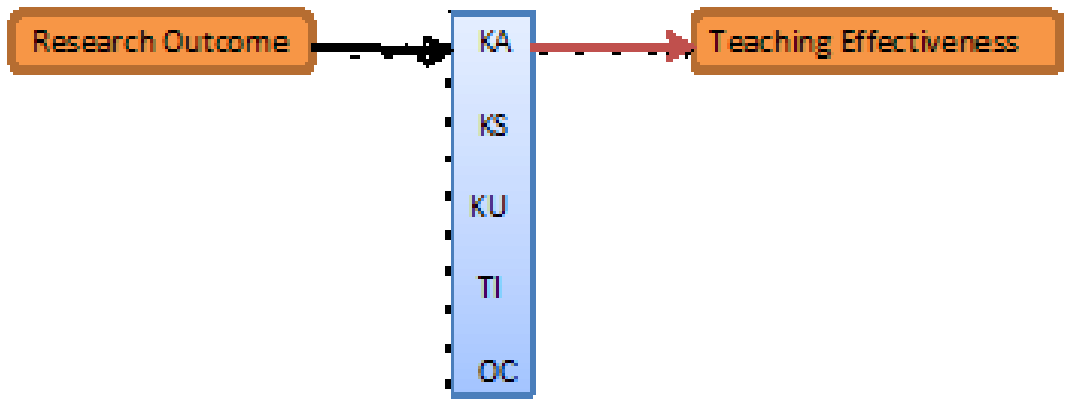

Figure 1. Study framework.

\section{Participants}

This study adopted purposive sampling method. The final sample consisted of 320 University staff, from Humanities Colleges. Four faculties were selectively chosen. They were College of Languages and Translation, College of Education, College of Sports Science and Physical Activity and College of Arts. Questionnaires were distributed to the academic staff, from senior lectures to professors. A total of 420 questionnaires were returned of which 100 copies were invalid, while 320 copies were valid.

\section{Tools}

KMC questionnaire. It was developed particularly for this study. It is composed of five subscales. They are: (KA), (KS), (KU), (TI), and (OC). Each of which has 8 items. The total items for the questionnaire is 40. The respondents were kindly asked to respond to each item using the Likert scale of 1-5 (1 being strongly disagree and 5 being strongly agree). R.Es. were: 0.90 for KA, 0.89 for KS, 0.83 for KU, 0.87 for TI, 0.88 for OC and 0.92 for total questionnaire. For convergent validity of KMC questionnaire, correlation with Wen-Ling \& Chun-Yen's KMC questionnaire (2016) was significant $[\mathrm{r}(320)=0.62$, $\mathrm{p}<0.01)$.

Research outcome Questionnaire (ROQ). It was developed particularly for this study. It consisted of 10 items measuring research outcome. The respondents were kindly asked to respond to each item using the Likert scale of 1-5 (1 being strongly disagree and 5 being strongly agree). The reliability of the scale in terms of IC was assessed by Cronbach's $\alpha$. $(\alpha=0.88)$. For convergent validity of Research outcome Questionnaire(ROQ), correlation with Wen-Ling \& Chun-Yen 's School effectiveness scale (2016) was significant $[\mathrm{r}(320)=0.63, \mathrm{p}<0.01)$.

Teaching Effectiveness Questionnaire (TEQ). It was developed particularly for this study. It consisted of 10 items measuring teaching effectiveness. The respondents were kindly asked to respond to each item using the Likert scale of $1-5$ ( 1 being strongly disagree and 5 being strongly agree). The reliability of the scale in terms of IC was assessed by Cronbach's $\alpha$. $(\alpha=0.91)$. For convergent validity of Teaching Effectiveness Questionnaire(TEQ), correlation with Wen-Ling \& Chun-Yen 's School effectiveness scale (2016) was significant $[\mathrm{r}(320)=0.61, \mathrm{p}<0.01)$.

\section{Data analysis}

PCA was conducted to measure the relationship between the study variables. SEM was employed to determine a valid causal model.

\section{Results and Discussion}

Descriptive Statistics 
Means, standard deviations, correlation, skewness and kurtosis among variables are shown in Table 1. All variables were highly correlated. Additionally. The skewness values are between 0.23 and 0.37 , and the kurtosis values are between -0.18 and -0.34 . This means that data was normally distributed (Kline, 2015).

Table 1.

Descriptive statistics and inter-correlations of knowledge management capabilities, research outcome and teaching effectiveness.

\begin{tabular}{|c|c|c|c|c|c|c|c|}
\hline Variables & 1 & 2 & 3 & 4 & 5 & 6 & 7 \\
\hline $\begin{array}{l}\text { Knowledge } \\
\text { Acquisition }\end{array}$ & & $0.59 * *$ & $0.60 * *$ & $0.62 * *$ & $0.63 * *$ & $0.49 * *$ & $0.53 * *$ \\
\hline $\begin{array}{l}\text { Knowledge } \\
\text { Sharing }\end{array}$ & $0.59 * *$ & & $0.54 * *$ & $0.58 * *$ & $0.61 * *$ & $0.51 * *$ & $0.56 * *$ \\
\hline $\begin{array}{l}\text { Knowledge } \\
\text { Utilization }\end{array}$ & $0.60 * *$ & $0.54 * *$ & & $0.59 * *$ & $0.63 * *$ & $0.61 * *$ & $0.66 * *$ \\
\hline $\begin{array}{l}\text { Technology } \\
\text { Infrastructure }\end{array}$ & $0.62 * *$ & $0.58 * *$ & $0.59 * *$ & & $0.54 * *$ & $0.55 * *$ & $0.62 * *$ \\
\hline $\begin{array}{l}\text { Organizational } \\
\text { Culture }\end{array}$ & $0.63 * *$ & $0.61 * *$ & $0.63 * *$ & $0.54 * *$ & & $0.61 * *$ & $0.64 * *$ \\
\hline $\begin{array}{l}\text { research } \\
\text { outcome }\end{array}$ & $0.49 * *$ & $0.51 * *$ & $0.61 * *$ & $0.55^{* *}$ & $0.61 * *$ & & $0.43 * *$ \\
\hline $\begin{array}{l}\text { teaching } \\
\text { effectiveness }\end{array}$ & $0.53 * *$ & $0.56^{* *}$ & $0.66^{* *}$ & $0.62 * *$ & $0.64 * *$ & $0.43 * *$ & \\
\hline Mean & 17.22 & 19.77 & 16.88 & 18.41 & 19.02 & 14.28 & 15.65 \\
\hline $\begin{array}{l}\text { Standard } \\
\text { deviation }\end{array}$ & 2.12 & 2.23 & 1.54 & 1.76 & 1.59 & 3.04 & 3.18 \\
\hline Skewness & 0.34 & 0.28 & 0.25 & 0.29 & 0.37 & 0.33 & 0.23 \\
\hline $\begin{array}{l}\text { Kurtosis } \\
* * \mathrm{P}<.01\end{array}$ & -0.18 & -0.22 & -0.33 & -0.34 & -0.19 & -0.31 & -0.24 \\
\hline
\end{tabular}

\section{SEM}

The model yielded a good fit with a significant chi square $\chi 2(39, \mathrm{~N}=320)=94$., $\mathrm{CFI}=0.92$, and RMSEA $=0.05$. The CFI value suggested an adequate fit. Figure 2 demonstrates all the SPC of the Model.

\section{Direct Effect}

Direct effects of KMC subscales on Research outcome and Teaching Effectiveness is presented in table 2. As shown in table 2., KA has significant direct effects on both $\mathrm{RO} \& \mathrm{TE}(\beta=0.47$, and 0.45 respectively), KS has significant direct effects on both $\mathrm{RO} \& \quad \mathrm{TE}(\beta=0.28$, and 0.26 respectively), KU has significant direct effects on both $\mathrm{RO} \& \mathrm{TE}(\beta=0.21$, and 0.23 respectively), $\mathrm{TI}$ has significant direct effects on both $\mathrm{RO} \& \mathrm{TE}(\beta=0.52$, and 0.49 respectively), and OC has significant direct effects on both $\mathrm{RO} \& \mathrm{TE}(\beta=0.54$, and 0.50 respectively)

Table 2.

Direct effects of KMC subscales on Research outcome and Teaching Effectiveness.

\begin{tabular}{|c|c|c|c|c|c|c|}
\hline IVs & & DVs & Esti. & S.E. & C.R. & $\mathrm{P}$. \\
\hline KA & $\rightarrow$ & $\begin{array}{l}\text { RO } \\
\text { TE }\end{array}$ & $\begin{array}{l}.47 \\
.45\end{array}$ & $\begin{array}{l}.11 \\
.10\end{array}$ & $\begin{array}{l}4.33 \\
4.18\end{array}$ & $\begin{array}{l}.00 \\
.00\end{array}$ \\
\hline $\mathrm{KS}$ & $\rightarrow$ & $\begin{array}{l}\text { RO } \\
\text { TE }\end{array}$ & $\begin{array}{l}.28 \\
.26\end{array}$ & $\begin{array}{l}.09 \\
.08\end{array}$ & $\begin{array}{l}3.24 \\
3.15\end{array}$ & $\begin{array}{l}.00 \\
.00\end{array}$ \\
\hline $\mathrm{KU}$ & $\rightarrow$ & $\begin{array}{l}\text { RO } \\
\text { TE }\end{array}$ & $\begin{array}{l}.21 \\
.23\end{array}$ & $\begin{array}{l}.06 \\
.07\end{array}$ & $\begin{array}{l}3.11 \\
3.05\end{array}$ & $\begin{array}{l}.00 \\
.00\end{array}$ \\
\hline TI & $\rightarrow$ & $\begin{array}{l}\text { RO } \\
\text { TE }\end{array}$ & $\begin{array}{l}.52 \\
.49\end{array}$ & $\begin{array}{l}.12 \\
.11\end{array}$ & $\begin{array}{l}5.01 \\
4.76\end{array}$ & $\begin{array}{l}.00 \\
.00\end{array}$ \\
\hline $\mathrm{OC}$ & $\rightarrow$ & $\begin{array}{l}\text { RO } \\
\text { TE }\end{array}$ & $\begin{array}{l}.54 \\
.50\end{array}$ & $\begin{array}{l}.13 \\
.12\end{array}$ & $\begin{array}{l}5.09 \\
4.77\end{array}$ & $\begin{array}{l}.00 \\
.00\end{array}$ \\
\hline
\end{tabular}




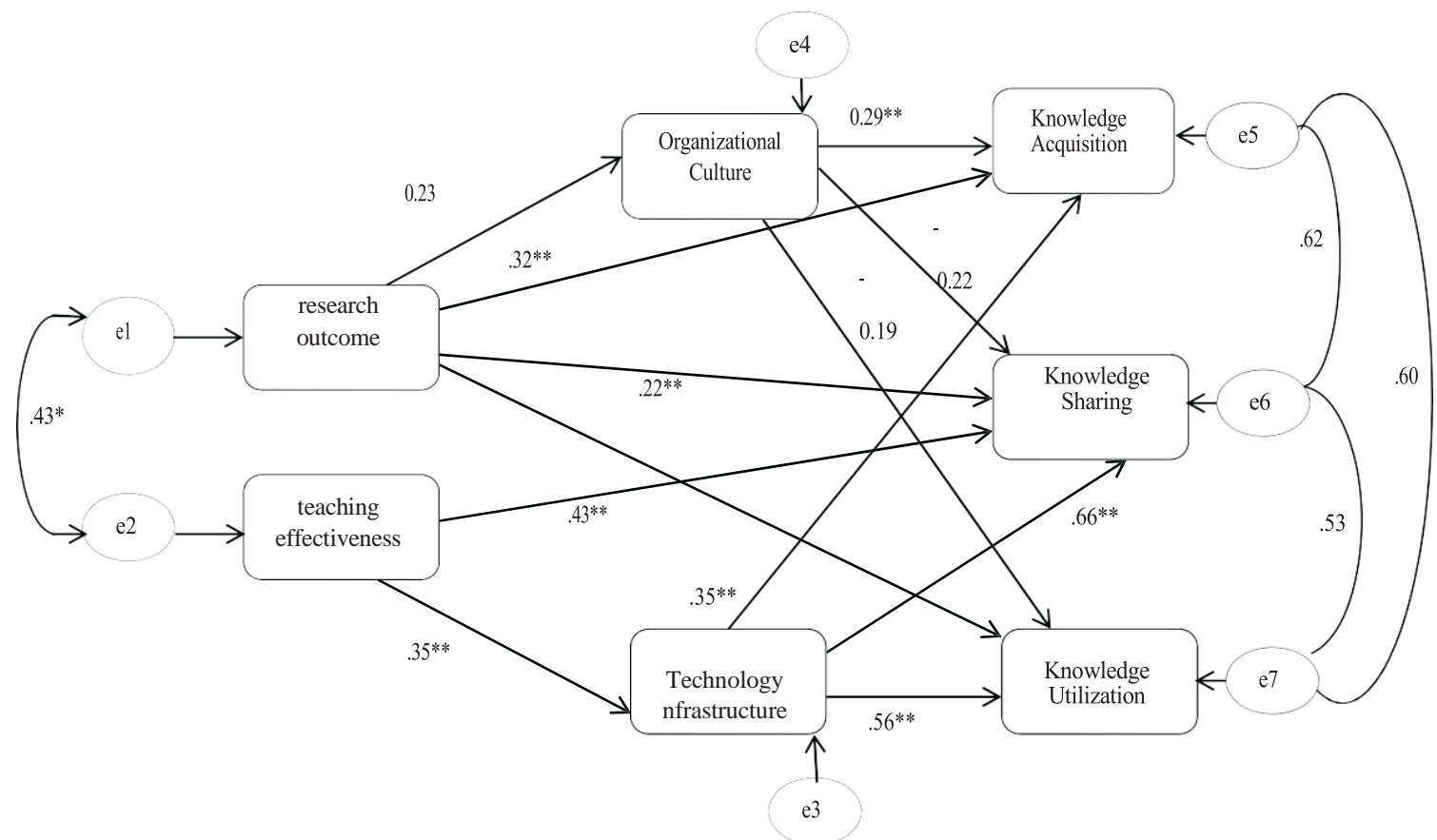

Figure 2. Result of Path Analysis.

The aim was to investigate effects of KMC on research outcome (RO) and teaching effectiveness (TE) in KSU. The results revealed that KA has significant direct effects on both RO \& TE, KS has significant direct effects on both RO \& TE, KU has significant direct effects on both RO \& TE, TI has significant direct effects on both RO \& TE, and OC has significant direct effects on both RO \& TE. This goes in the same line with the findings of Wen-Ling \& Chun-Yen (2016) who found that KMPC predict the perceived school effectiveness. This emphasized that knowledge is supposed to the main resource of HEIs in the knowledge economy, and an important factor that services to empower HEIs to be competitive organizations. KA, KS, $\mathrm{KU}$, TI, and OC can be effective tools in helping University Staff with KM activities. When KM is introduced into HEIs, research outcome (RO) and teaching effectiveness (TE) can be improved and be of high quality. It is recommended that research outcome (RO) and teaching effectiveness (TE) in KSU may be established when HEIs' staff process KMC activities. If HEIs hope to effectively achieve research outcome (RO) and teaching effectiveness (TE), KMC will come at the forefront.

Results of Pearson's correlation indicated that all variables were highly correlated. Additionally. The skewness values are between 0.23 and 0.37 , and the kurtosis values are between -0.18 and -0.34 . This finding goes in the same line with Ammar, Lim \& Siti's results (2012).

\section{Conclusions}

This study extended our knowledge on the effect of KMC on research outcome (RO) and teaching effectiveness (TE) in KSU and provided insight into the relationships between KM capabilities on research outcome (RO) and teaching effectiveness (TE) in KSU. It also could fill the gaps concerning the relationships between KM capabilities, research outcome (RO) and teaching effectiveness(TE) in KSU. It may allow policy makers to gain in-depth understanding of the effect of KMC on research outcome (RO) and teaching effectiveness(TE) in KSU.

\section{References}

Abdulrahman, G., Mohamad, F., Najma, I. \& Imtiaz, A. (2018) Knowledge Management Practice in Private Sector: Building the Way for Saudi Arabia Strategic Growth and Transformation To Knowledge-Based Economy. International Journal of Engineering \& Technology, 7 (2.34), 69-73 
Ali, A. Teong, L. \& Othman, S. (2012). Knowledge management processes and school effectiveness in Iraqi HEIs: an empirical investigation. International Journal of Academic Research in Business and Social Sciences, 2(6), 273-293.

Ammar, A, Lim, K. \& Siti, N. (2012). Knowledge Management Processes and Academic Performance in Iraqi HEIs: An Empirical Investigation. International Journal of Academic Research in Business and Social Sciences, 2(6), 273-293

Balakrishnan, V. \& Chandramalar, M. (2019). Knowledge management practices An exploratory study at the Malaysian higher education institutions. Journal of Research in Innovative Teaching \& Learning. Emerald Publishing Limited, Vol 13(2). DOI: 10.1108/JRIT-01-2019-0008

Cranfield, D.J. and Taylor, J. (2008).Knowledge management and higher education: a UK case study. The Electronic Journal of Knowledge Management, 6(2), 85-100.

Donate, J. and Canales, I. (2012).A new approach to the concept of knowledge strategy. Journal of Knowledge Management, 16(1), 22-44.

Fullwood, R., Rowley, J. \& Delbridge, R. (2013).Knowledge sharing amongst academics in UK universities". Journal of Knowledge Management, 17(1), 123-136.

Hossain, L., Atkinson, S., D’eredita, M. and Wigand, R. (2013), “Towards a mech-organic perspective for knowledge sharing networks in organisations". UK Academy for Information Systems, Worcester College University of Oxford, 8-20 March.

Huang, L.S. \& Lai, C.P. (2014).Knowledge management adoption and diffusion using structural equation modelling. Global Journal of Business Research, 8 (1), 39-56.

Kline, R. (2015). Principles and Practice of Structural Equation Modeling, 4th ed., New. York, NY: Guilford.

Loh, B., Tang, A., Menkhoff, T., Chay, Y.W. and Evers, H. (2010), “Applying knowledge management in university research". Singapore, Hackensack, NJ and London: World Scientific Publishing, pp. 221-248.

Machado, C., \& Davim, J. (2013). Knowledge Management Fostering Innovation: balancing Practices and Enabling Contexts", in Management and Engineering Innovation (eds C. Machado and J. P. Davim). Hoboken, NJ USA: John Wiley \& Sons, Inc. doi: 10.1002/9781118733202.ch6

Maricris, P., Gerby, R., \& Kimry, D. (2019). Knowledge Management Practices in Private Higher Educational Institutions in the Philippines. NOCEI Journal, 3(1), pp 1-18.

Martínez, C. (2019). Responsabilidad social universitaria, transferencia tecnológica y desarrollo endógeno. Estrategias de vinculación comunitaria. Revista Latinoamericana de Difusión Científica, 1 (1), 55-67.

Ministry of Economy and Planning (2010-2014). Brief report on the ninth development plan," vol. 1431/32-14, pp. 2-85, 2014.

Muhammad, N., Rahman, B.A., Abd Rahman, W.Z., Idris, A.R., Sabri, S.M. and Jusoff, K. (2011). Knowledge management practices (KMP) and school effectiveness in Universiti Teknologi Mara (UITM) Terengganu, Malaysia. World Applied Sciences Journal, 12, 21-26.

Omerzel, D.G., Biloslavo, R. and Trnavčevič, A. (2011). Knowledge management and organizational culture in higher education institutions. Journal for East European Management Studies, Vol. 16 (2), pp. 111-139.

Osama, A., Ramzi E., \& Tillal, E. (2018). Knowledge sharing in higher education institutions: a systematic review. Journal of Enterprise Information Management, 31(2), 226-246

Pinto, M. (2014). Knowledge management in higher education institutions: a framework to improve collaboration. In The 9th Iberian Conference on Information Systems and Technologies (CISTI), Barcelona 18-21 June, pp. 1-4. IEEE. doi: 10.1109/CISTI.2014.6876876

Wen-Ling, S. \& Chun-Yen, T. (2016). The effects of knowledge management capabilities on perceived school effectiveness in career and technical education. Journal of Knowledge Management, 20(6), 1373-1392. 